\title{
Association of geomagnetic disturbances and suicides in Japan, 1999-2010
}

\author{
Harue Tada $\cdot$ Tsutomu Nishimura $\cdot$ \\ Eiji Nakatani $\cdot$ Kazuki Matsuda $\cdot$ Satoshi Teramukai \\ Masanori Fukushima
}

Received: 13 July 2011/Accepted: 16 July 2013/Published online: 5 September 2013

(C) The Japanese Society for Hygiene 2013

\begin{abstract}
Objectives Previous studies have shown a positive relationship between geomagnetic disturbances and an increased incidence of suicide. The Japanese suicide rate is the ninth highest in the world, but there have been no reports examining the relationship between geomagnetic disturbance and the number of suicides, and, therefore, this paper examines this relationship.

Methods The number of Japanese suicides per month from January 1999 to December 2010 was obtained, and it was found that a total of 262,596 males and 102,539 females committed suicide during this period. To adjust the other factors which affect the number of suicides, a multiple linear regression analysis with backward elimination was carried out, with the monthly number of suicides as the response variable and the monthly mean $K$ index value, monthly mean number of sunspots, monthly mean unemployment rate, proportion of elderly people (\%), monthly mean air pressure $(\mathrm{hPa})$, monthly mean air temperature $\left({ }^{\circ} \mathrm{C}\right)$, monthly mean humidity $(\%)$, and monthly mean day length (h) as the explanatory variables.
\end{abstract}

H. Tada and T. Nishimura contributed equally to this work.

H. Tada $\cdot$ E. Nakatani $\cdot$ S. Teramukai

Translational Research Center, Kyoto University Hospital, 54

Shogoin Kawahara-cho, Sakyo-ku, Kyoto 606-8507, Japan

T. Nishimura $(\bowtie) \cdot$ E. Nakatani $\cdot$ M. Fukushima

Translational Research Informatics Center, 1-5-4 Minatojima-

minamimachi, Chuo-ku, Kobe 650-0047, Japan

e-mail: t246ra@kuhp.kyoto-u.ac.jp

K. Matsuda

Image Processing Laboratory, Nara Institute of Science and

Technology, 8916-5 Takayama, Ikoma, Nara 630-0192, Japan
Results In the multiple linear regression analysis for males, the monthly mean $K$ index value was associated with the monthly number of suicides, but in females, the monthly mean $K$ index value was not associated with the monthly number of suicides.

Conclusion In this study, we generated a hypothesis that geomagnetic disturbances may trigger male suicides.

Keywords Suicide - Geomagnetic field .

Geomagnetic storm · Electromagnetic field

\section{Introduction}

Suicide is an enormous public health problem throughout the world. Every year, about 800,000 to one million people commit suicide worldwide, making it a significant cause of death [1]. Risk factors associated with completed suicides have been identified, such as psychiatric illness, hopelessness, previous suicide attempts, being widowed or divorced, living alone, having a recent adverse event, having severe anxiety, having a chronic medical illness, and having a family history of suicide attempts or completions [2]. There have been some reports that environmental factors, such as electromagnetic fields [3, 4], latitude [5, 6], and season [57] were associated with suicides.

There have been epidemiologic studies reporting a possible relationship between electromagnetic fields at electric power companies or near power lines and depression or suicides [3, 4, 8]. The Earth has a geomagnetic field which is constantly changing. Although Table 1 summarizes reports of studies with different designs (case-control study, ecological study) and endpoints (suicide and depression), previous studies have shown a positive relationship between geomagnetic disturbances and an 
Table 1 Articles investigating the relationship between changes in magnetic fields and suicides or depression

\begin{tabular}{|c|c|c|c|c|c|c|}
\hline No. & Authors & Country & Study period & $\begin{array}{l}\text { No. of } \\
\text { suicides/ } \\
\text { admissions }\end{array}$ & $\begin{array}{l}\text { Relationship } \\
\text { investigated }\end{array}$ & Results \\
\hline 1 & Kay [40] & England & $\begin{array}{l}\text { January } 1976- \\
\text { December } \\
1986\end{array}$ & $\begin{array}{l}1,042 \text { male } \\
\text { and } 2,407 \\
\text { female } \\
\text { admissions }\end{array}$ & $\begin{array}{l}\text { Geomagnetic storms } \\
\text { and the incidence of } \\
\text { depression }\end{array}$ & $\begin{array}{l}\text { There is statistically significant } 36.2 \% \\
\text { increase in male hospital admissions with a } \\
\text { diagnosis of depressed phase, manic- } \\
\text { depressive illness in the second week } \\
\text { following such storms }\end{array}$ \\
\hline 2 & $\begin{array}{l}\text { Gordon and } \\
\text { Berk [9] }\end{array}$ & $\begin{array}{l}\text { South } \\
\text { Africa }\end{array}$ & $\begin{array}{l}\text { January } 1980- \\
\text { December } \\
1992\end{array}$ & $\begin{array}{l}1,200 \text { males } \\
\text { and } 287 \\
\text { females }\end{array}$ & $\begin{array}{l}\text { Geomagnetic storm } \\
\text { activity and suicide } \\
\text { rates }\end{array}$ & $\begin{array}{l}\text { A significant correlation was found between } \\
\text { the mean total number of suicides and the } \\
\text { mean average storm activity during the } \\
\text { same period. This correlation was true of } \\
\text { both male and female suicides }\end{array}$ \\
\hline 3 & $\begin{array}{l}\text { Partonen } \\
\text { et al. [7] }\end{array}$ & Finland & $\begin{array}{l}\text { January 1979- } \\
\text { December } \\
1999\end{array}$ & $\begin{array}{l}21,622 \\
\text { males and } \\
5,847 \\
\text { females }\end{array}$ & $\begin{array}{l}\text { The effect of solar } \\
\text { radiation and } \\
\text { geomagnetic activity } \\
\text { on the frequency of } \\
\text { suicides }\end{array}$ & $\begin{array}{l}\text { High levels of solar radiation activity were } \\
\text { associated with an increased risk of suicide, } \\
\text { but the effect of geomagnetic activity was } \\
\text { weak }\end{array}$ \\
\hline 4 & Berk et al. [10] & Australia & $\begin{array}{r}\text { January } 1968- \\
\text { August } 2002\end{array}$ & $\begin{array}{l}51,845 \\
\text { males and } \\
16,327 \\
\text { females }\end{array}$ & $\begin{array}{l}\text { Geomagnetic storm } \\
\text { activity and suicides }\end{array}$ & $\begin{array}{l}\text { Suicide amongst females increased } \\
\text { significantly in autumn during concurrent } \\
\text { periods of geomagnetic storm activity. This } \\
\text { pattern was not observed in males }\end{array}$ \\
\hline 5 & Brahic [11] & Russian & 1948-1997 & Unknown & $\begin{array}{l}\text { Geomagnetic peaks } \\
\text { and number of } \\
\text { suicides }\end{array}$ & $\begin{array}{l}\text { The geomagnetism peaks matched up with } \\
\text { peaks in the number of suicides }\end{array}$ \\
\hline 6 & Present study & Japan & $\begin{array}{l}\text { January 1999- } \\
\text { December } \\
2010\end{array}$ & $\begin{array}{l}262,596 \\
\text { males and } \\
102,539 \\
\text { females }\end{array}$ & $\begin{array}{l}\text { Geomagnetic activity } \\
\text { and number of } \\
\text { suicides }\end{array}$ & $\begin{array}{l}\text { There was a statistically significant } \\
\text { relationship found between the number of } \\
\text { male suicides and the } K \text { index value }\end{array}$ \\
\hline
\end{tabular}

increased incidence of suicide [7, 9-11]. However, there have also been studies in which suicide numbers were found to be inversely related to geomagnetic activity $[12,13]$.

The $K$ indices, devised by Bartels et al., provide an objective method of monitoring the effects of the solar wind and interplanetary magnetic field effects on the magnetic field of the Earth [14]. It is routine to use them as indices of magnetic activity at permanent magnetic observatories and temporary stations [14]. The basis of the $K$ indices is the range of irregular variations in geomagnetic fields, which are measured for the two horizontal geomagnetic components, after eliminating so-called non$K$ variations [14]. Sudden fluctuations can be observed during large geomagnetic storms for $1 \pm 2$ days [15]. These are caused by the superimposition of equatorial ring current effects and auroral current effects, and generate field variations as large as $200 \pm 300 \mathrm{nT}$ at low latitudes and can exceed 1,000 nT at high latitudes [15]. Partonen et al. [7] found a relationship between the smoothed monthly mean index of geomagnetic activity and the relative risk of suicide $(n=27,469)$ in Finland. Additionally, Gordon and Berk [9] found a relationship between the average storm activity and the number of suicides in South Africa. Shumilov looked at activity in the Earth's geomagnetic field from 1948 to 1997 and found that it was grouped into three seasonal peaks every year: one from March to May, another in July, and the last in October [11]. $\mathrm{He}$ also found that the geomagnetic peaks matched up with peaks in the number of suicides in the northern Russian city of Kirovsk over the same period [11]. A large problem in most previous studies was that they only analyzed the relationship between geomagnetic disturbance and the number of suicides, but did not adjust for other variables.

In Japan, daily suicide data are not available from the Japanese national statistics website [16], but monthly suicides data are. If geomagnetic storms can desynchronize circadian rhythms and melatonin production, as has been reported previously [17], there is a possibility that the effect does not have a quick impact but, rather, a slow one. We, therefore, believe that an analysis using monthly suicides and geomagnetic activity data is meaningful. In addition, in Japan, about thirty thousand people commit suicide per year [16]. The suicide rate in Japan is the ninth highest in the world [18], but there have been no reports examining the relationship between geomagnetic disturbance and the number of suicides, and, therefore, the present paper examines this relationship adjusted for other factors in order to generate a hypothesis. 


\section{Materials and methods}

Monthly suicide data for the period from January 1999 to December 2010 were obtained from the Japanese national statistics website [16]. A total of 262,596 males and 102,539 females committed suicide during this period. $K$ index values were obtained from the website of the Magnetic Observatory, Japan Meteorological Agency [19]. $K$ index values from three observatories were obtained (Kakioka, Memanbetsu, and Kanoya) for each month from January 1999 to December 2010. The mean $K$ index value was defined as the average value at the three observatories. Monthly mean unemployment rate (\%) data were added to the analysis as an economic variable. Monthly mean unemployment rate data were obtained from the Japanese national statistics website [20]. The monthly number of sunspots was added to the analysis because the number of sunspots has an 11-year cycle, which may have effects on economics [21]. Otsu et al. [22] found, based on data from Japan between 1971 and 2001, a significant negative correlation between sunspot numbers and the unemployment rate. Data on the monthly number of sunspots from January 1999 to December 2010 were obtained from the Solar Influences Data Analysis Center [23]. We obtained the monthly mean air pressure (hPa), monthly mean air temperature $\left({ }^{\circ} \mathrm{C}\right)$, monthly mean humidity $(\%)$, and monthly mean day length (h) data of each prefectural capital from January 1999 to December 2010 from the Japan Meteorological Agency website (Tokyo) [24]. The national monthly mean values were defined as the average values at the 47 prefectures. The proportion of elderly people in the population (\%) was defined as the number of elderly persons aged 65 years or older divided by the overall population in the same year. The number of elderly persons aged 65 years or older and overall population data from January 1999 to December 2010 were obtained from the Japanese national statistics website [25].

\section{Statistical analysis}

We conducted a regression analysis to examine the relationship between geomagnetic disturbance and the number of suicides, firstly carrying out a simple regression analysis. The monthly number of suicides was taken as the response variable, and the explanatory variable was the monthly mean $K$ index value, monthly mean number of sunspots, monthly mean unemployment rate $(\%)$, proportion of elderly people $(\%)$, monthly mean air pressure $(\mathrm{hPa})$, monthly mean air temperature $\left({ }^{\circ} \mathrm{C}\right)$, or monthly mean humidity (\%), as well as the monthly mean day length (h). Secondly, to adjust the other factors which affect the number of suicides, we conducted a multiple linear regression analysis with backward elimination. The monthly number of suicides was taken as the response variable and the monthly mean $K$ index value, monthly mean number of sunspots, monthly mean unemployment rate (\%), proportion of elderly people in the population $(\%)$, monthly mean air pressure (hPa), monthly mean air temperature $\left({ }^{\circ} \mathrm{C}\right)$, monthly mean humidity $(\%)$, and monthly mean day length (h) were the explanatory variables. Analyses were carried out separately for each gender. A $P$-value of 0.05 or less was taken to indicate statistical significance. Statistical analyses were performed using SAS version 9.2 (SAS Institute, Cary, NC, USA).

\section{Results}

Changes in the monthly number of male and female suicides and monthly $K$ index values are shown in Fig. 1a and b. The $K$ index has been falling since about 2006 . Male suicides have been fluctuating within the range of approximately 1,500-2,300 per year (Fig. 1a), while female suicides have been have been fluctuating within the range of approximately $600-900$ per year (Fig. 1b). The monthly mean number of male and female suicides and the monthly $K$ index value by calendar month are shown in Fig. 1c and d. It was found that male suicides increase in spring, and gradually decline thereafter, and then increase again in October (Fig. 1c). The $K$ index increases in spring, then gradually decreases, and increases again in August and October (Fig. 1c). It was found that female suicides increase in spring, gradually decline thereafter, and then increase again in October (Fig. 1d).

Changes in the monthly number of male and female suicides and the monthly number of sunspots are shown in Fig. 1e and $\mathrm{f}$. It has been observed that that there has been a tendency for the number of sunspots to decrease since 2002 (Fig. 1e, f). The monthly mean number of male and female suicides and the monthly mean number of sunspots by calendar month are shown in Fig. 1g and h. Changes in the monthly number of male and female suicides and the monthly unemployment rate $(\%)$ are shown in Fig. 1i and j. The male unemployment rate gradually decreased from about 2003; however, it increased from about 2009 (Fig. 1i). A similar trend in female unemployment as that of males was observed (Fig. 1j). The monthly mean air pressure $(\mathrm{hPa})$, monthly mean air temperature $\left({ }^{\circ} \mathrm{C}\right)$, monthly mean humidity (\%), and monthly mean day length (h) by calendar month are shown in Table 2 . We defined the mean $K$ index value as the average value at three observatories (Kakioka, Memanbetsu, and Kanoya). The average values of Kakioka, Memanbetsu, and Kanoya were $13.2 \pm 4.4$ (range 3.2-22.6), $14.7 \pm 4.5$ (range 3.4-24.8), 

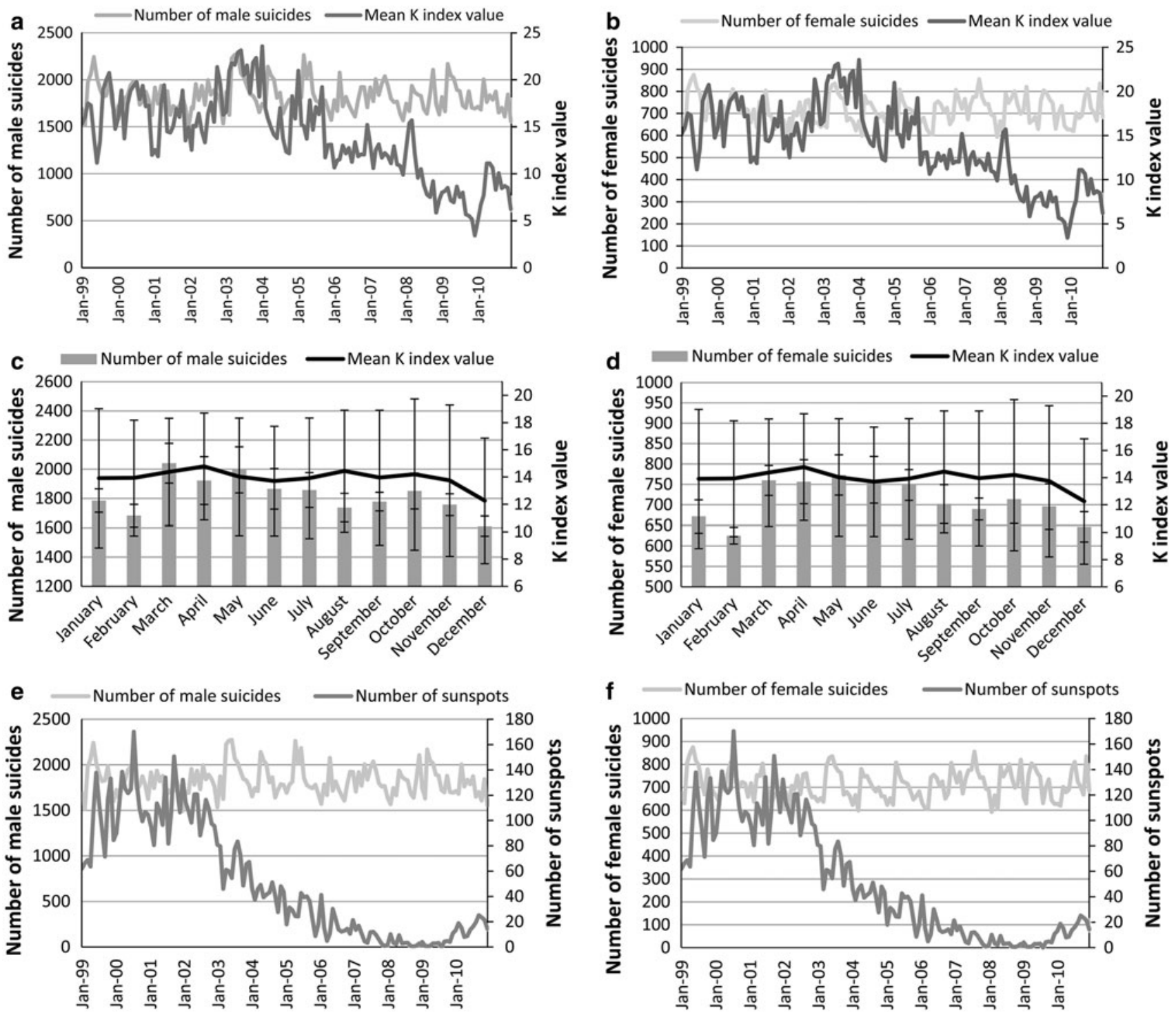

Fig. 1 a Changes in the monthly number of male suicides and monthly $K$ index values from January 1999 to December 2010. b Changes in the monthly number of female suicides and monthly $K$ index values from January 1999 to December 2010. c Monthly mean number of male suicides (mean \pm SD) and monthly mean $K$ index value (mean \pm SD) by calendar month (January 1999December 2010). d Monthly mean number of female suicides (mean $\pm \mathrm{SD}$ ) and monthly mean $K$ index value (mean $\pm \mathrm{SD}$ ) by calendar month (January 1999-December 2010). e Changes in the monthly number of male suicides and monthly number of sunspots from January 1999 to December 2010. f Changes in the monthly

and $13.9 \pm 4.5$ (range 3.7-23.3). There was a statistically significant correlation between the $K$ values at Kakioka and Kanoya $(r=0.99, P<0.001)$, those at Kakioka and Memanbetsu $(r=0.99, P<0.001)$, and those at Kanoya and Memanbetsu $(r=0.99, P<0.001)$. Therefore, we consider our definition of the $K$ index value to be appropriate. We conducted a regression analysis to examine the impact of geomagnetic disturbance on the monthly number

number of female suicides and monthly number of sunspots from January 1999 to December 2010. g Monthly mean number of male suicides (mean $\pm \mathrm{SD}$ ) and monthly mean number of sunspots (mean \pm SD) by calendar month (January 1999-December 2010). h Monthly mean number of female suicides (mean \pm SD) and monthly mean number of sunspots (mean \pm SD) by calendar month (January 1999-December 2010). i Changes in the monthly number of male suicides and monthly unemployment rate (\%) from January 1999 to December 2010. j Changes in the monthly number of female suicides and monthly unemployment rate (\%) from January 1999 to December 2010

of suicides, as described in the statistical analysis section above.

Results of simple regression analysis

In a simple linear regression analysis for males, the monthly mean $K$ index values, monthly mean unemployment rate $(\%)$, monthly mean air pressure $(\mathrm{hPa})$, and 

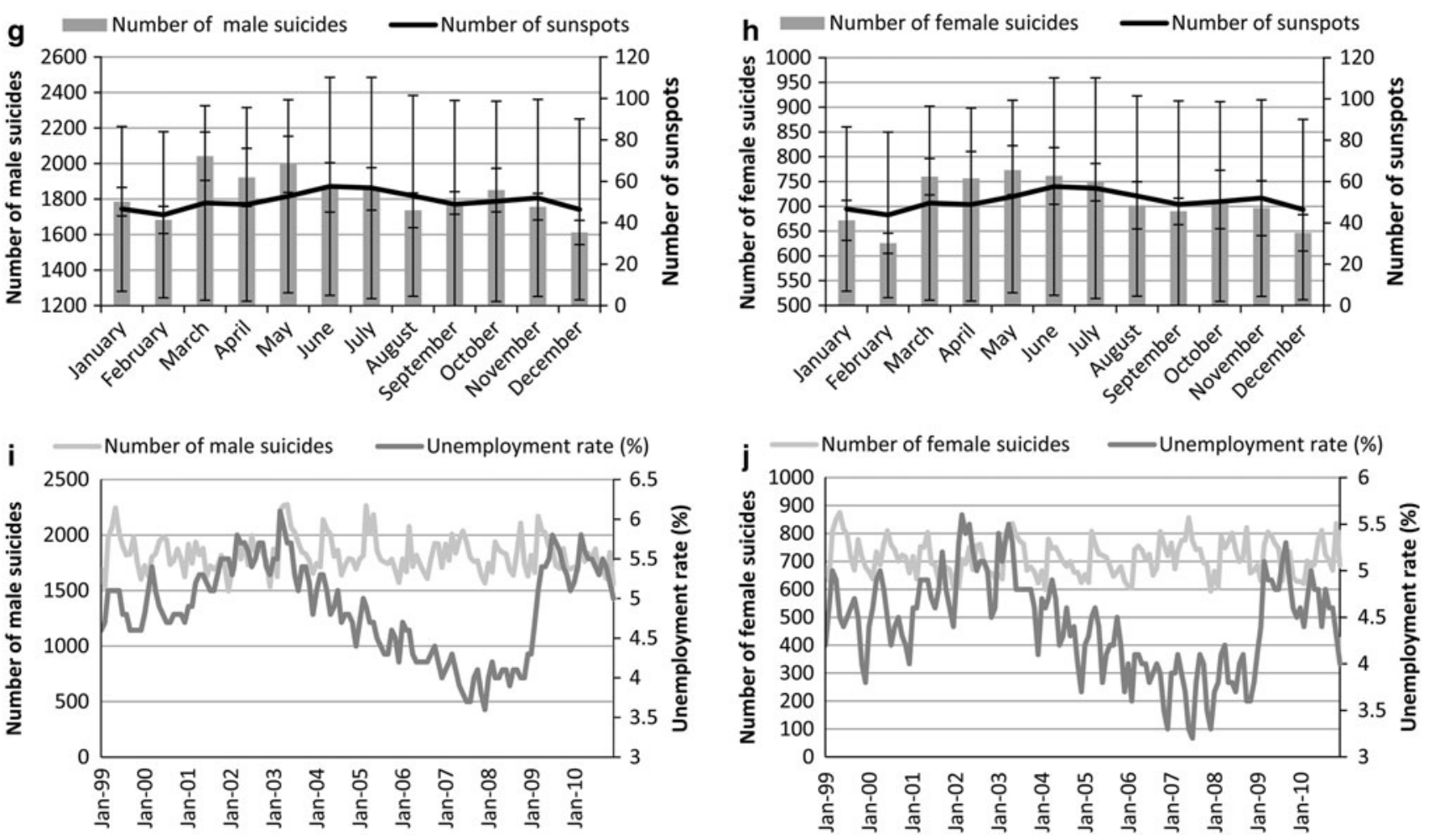

Fig. 1 continued

monthly mean day length (h) were associated with the monthly number of suicides (Table 3), but the monthly mean number of sunspots, proportion of elderly people $(\%)$, monthly mean air temperature $\left({ }^{\circ} \mathrm{C}\right)$, and monthly mean humidity (\%) were not associated with the monthly number of suicides (Table 3). Also, in a simple regression analysis for females, the monthly mean air pressure $(\mathrm{hPa})$, monthly mean air temperature $\left({ }^{\circ} \mathrm{C}\right)$, and monthly mean day length (h) were associated with the monthly number of suicides (Table 3), but the monthly mean $K$ index values, monthly mean number of sunspots, monthly mean unemployment rate $(\%)$, proportion of elderly people (\%), and monthly mean humidity $(\%)$ were not associated with the monthly number of suicides (Table 3).

Results of multiple linear regression analysis

In a multiple linear regression analysis of males, the mean $K$ index value, monthly mean number of sunspots, monthly mean unemployment rate $(\%)$, monthly mean air pressure $(\mathrm{hPa})$, and monthly mean humidity $(\%)$ were associated with the monthly number of suicides (Table 4), and in the multiple linear regression analysis of females, the monthly mean air pressure $(\mathrm{hPa})$ and monthly mean day length (h) were associated with the monthly number of suicides (Table 4).

\section{Discussion}

To adjust the other factors which affect the number of suicides, a multiple linear regression analysis with backward elimination was carried out, with the monthly number of suicides as the response variable and the monthly mean $K$ index value, monthly mean number of sunspots, monthly mean unemployment rate, proportion of elderly people in the population, monthly mean air pressure $(\mathrm{hPa})$, monthly mean air temperature $\left({ }^{\circ} \mathrm{C}\right)$, monthly mean humidity (\%), and monthly mean day length (h) as the explanatory variables. In the multiple linear regression analysis for males, the monthly mean $K$ index value was associated with the monthly number of suicides, but in the multiple linear regression analysis of females, the monthly mean $K$ index value was not associated with the monthly number of suicides. After adjusting for weather data, the unemployment rate, and sunspot numbers there was still a significant relationship between the $K$ index and the number of suicides in males. On a simple linear regression, there was no significant relationship between the number of sunspots and the number of suicides; however, on a multiple linear regression analysis, there was a significant negative relationship. Similarly, while there was a significant positive correlation found on a simple regression analysis between the number of suicides and day length, there was no significance with multiple regression analysis, and the causes of this are unknown. 
Table 2 Monthly mean air pressure (hPa), monthly mean air temperature $\left({ }^{\circ} \mathrm{C}\right)$, monthly mean humidity $(\%)$, and monthly total day length (h) by calendar month in Japan

\begin{tabular}{lllll}
\hline $\begin{array}{l}\text { Calendar } \\
\text { month }\end{array}$ & $\begin{array}{l}\text { Monthly mean air } \\
\text { pressure }(\mathrm{hPa}) \pm \mathrm{SD}\end{array}$ & $\begin{array}{l}\text { Monthly mean air } \\
\text { temperature }\left({ }^{\circ} \mathrm{C}\right) \pm \mathrm{SD}\end{array}$ & $\begin{array}{l}\text { Monthly mean } \\
\text { humidity }(\%) \pm \mathrm{SD}\end{array}$ & $\begin{array}{l}\text { Monthly total day } \\
\text { length }(\mathrm{h}) \pm \mathrm{SD}\end{array}$ \\
\hline January & $1,011.7 \pm 10.1$ & $4.6 \pm 3.3$ & $65.8 \pm 8.7$ & $132.3 \pm 49.8$ \\
February & $1,011.6 \pm 9.8$ & $5.4 \pm 3.5$ & $64.8 \pm 8.1$ & $136.1 \pm 42.2$ \\
March & $1,009.5 \pm 9.6$ & $8.4 \pm 3.1$ & $62.8 \pm 6.4$ & $165.7 \pm 34.9$ \\
April & $1,008.0 \pm 9.1$ & $13.7 \pm 2.6$ & $63.0 \pm 5.6$ & $181.4 \pm 35.2$ \\
May & $1,005.3 \pm 8.7$ & $18.4 \pm 2.1$ & $67.2 \pm 5.3$ & $186.2 \pm 34.4$ \\
June & $1,002.8 \pm 8.5$ & $22.3 \pm 1.8$ & $73.0 \pm 4.8$ & $149.8 \pm 32.3$ \\
July & $1,002.1 \pm 8.5$ & $25.9 \pm 2.2$ & $75.0 \pm 5.1$ & $160.3 \pm 56.5$ \\
August & $1,003.7 \pm 8.3$ & $27.1 \pm 1.8$ & $72.4 \pm 4.9$ & $194.6 \pm 41.8$ \\
September & $1,006.6 \pm 8.4$ & $23.8 \pm 2.1$ & $70.1 \pm 4.9$ & $158.2 \pm 30.0$ \\
October & $1,010.4 \pm 8.7$ & $17.9 \pm 2.5$ & $69.0 \pm 5.8$ & $157.9 \pm 27.6$ \\
November & $1,012.3 \pm 9.2$ & $12.0 \pm 3.0$ & $67.2 \pm 7.7$ & $138.6 \pm 33.0$ \\
December & $1,012.0 \pm 10.1$ & $6.9 \pm 3.3$ & $135.1 \pm 47.0$ \\
\hline
\end{tabular}

Since there are no air pressure and humidity data within the observation data for Saitama City, the capital of Saitama Prefecture, the air pressure and humidity data from Kumagaya City were used

Since there are no air pressure and humidity data within the observation data for Otsu City, the capital of Shiga Prefecture, the air pressure and humidity data from Hikone City were used

Table 3 Results of simple regression analysis investigating the number of suicides against the monthly mean $K$ index value, monthly mean sunspot numbers, monthly unemployment rate $(\%)$, proportion of elderly people in the population (\%), monthly mean air pressure (hPa), monthly mean air temperature $\left({ }^{\circ} \mathrm{C}\right)$, monthly mean humidity $(\%)$, and monthly mean day length (h)

\begin{tabular}{|c|c|c|c|c|c|c|}
\hline \multirow[t]{2}{*}{ Covariates } & \multicolumn{3}{|l|}{ Male } & \multicolumn{3}{|l|}{ Female } \\
\hline & Coefficient & SE & $P$-value & Coefficient & SE & $P$-value \\
\hline$K$ index value & 7.6 & 3.0 & 0.01 & 0.74 & 1.19 & 0.54 \\
\hline Sunspot numbers & 0.16 & 0.30 & 0.59 & 0.04 & 0.12 & 0.75 \\
\hline Unemployment rate $(\%)$ & 52.0 & 23.1 & 0.03 & 8.0 & 10.3 & 0.44 \\
\hline Proportion of elderly people in the population (\%) & -5.8 & 7.1 & 0.42 & -0.41 & 2.5 & 0.87 \\
\hline Air pressure $(\mathrm{hPa})$ & -9.2 & 3.4 & 0.007 & -6.8 & 1.2 & $<0.0001$ \\
\hline Air temperature $\left({ }^{\circ} \mathrm{C}\right)$ & 2.7 & 1.7 & 0.11 & 2.9 & 0.6 & $<0.0001$ \\
\hline Humidity (\%) & -3.9 & 3.0 & 0.19 & 1.9 & 1.2 & 0.12 \\
\hline Day length (h) & 1.5 & 0.4 & 0.0009 & 0.67 & 0.17 & $<0.0001$ \\
\hline
\end{tabular}

Table 4 Results of multiple linear regression analysis

\begin{tabular}{|c|c|c|c|c|c|c|}
\hline \multirow[t]{2}{*}{ Covariates } & \multicolumn{3}{|l|}{ Male } & \multicolumn{3}{|l|}{ Female } \\
\hline & Coefficient & SE & $P$-value & Coefficient & SE & $P$-value \\
\hline$K$ index value & 11.4 & 3.5 & 0.001 & - & - & - \\
\hline Sunspot numbers & -0.86 & 0.37 & 0.02 & - & - & - \\
\hline Unemployment rate $(\%)$ & 54.2 & 23.9 & 0.03 & - & - & - \\
\hline Air pressure $(\mathrm{hPa})$ & -14.9 & 3.6 & $<0.0001$ & -5.6 & 1.3 & $<0.0001$ \\
\hline Humidity (\%) & -9.2 & 3.2 & 0.004 & - & - & - \\
\hline Day length (h) & - & - & - & 0.38 & 0.17 & 0.03 \\
\hline
\end{tabular}

Valuables with $P<0.05$ were selected using a backward elimination procedure

The monthly mean number of suicides was found to increase in March to June (Fig. 1c, d). These results correspond with previous reports showing the number of suicides to increase in spring [5-7]. We identified a relationship between geomagnetic disturbance and male suicides. This raises the question as to why males are 
influenced by geomagnetic disturbances but females are apparently not. Previous reports have not found gender differences [7, 9], but there is some evidence for such differences in the effects of various types of magnetic field [26-31].

Our results do not agree with some studies in which suicide numbers were found to be inversely related to geomagnetic activity $[12,13]$. In a study, Stoupel et al. analyzed data from 1990 to 2002 [13]. In 1991, Lithuania became independent from the Soviet Union. In 1995, Lithuania had the highest suicide rate in the world, at 45.6 per 100,000 people. Therefore, other factors such as changes in living conditions may affect the number of suicides.

Regarding the potential mechanism connecting geomagnetic disturbances and suicides, one hypothesis involves the effect of magnetic fields on opioid receptors. It has been shown that exposure to magnetic fields has opioid-mediated behavioral effects in rats, mice, land snails, and humans [32]. As an example, exposure to pulsed magnetic fields was found to have significant antinociceptive or "analgesic" effects in Cepaea nemoralis, the land snail, demonstrated increased latency of response to a warmed $\left(40^{\circ} \mathrm{C}\right)$ surface [33]. Attenuation of pulsed magnetic field-induced analgesia by naloxone, an opioid antagonist, as well as by mu and delta opioid receptor antagonists, provides further support for the role of opioids in the mediation of such analgesia [33, 34]. Furthermore, these effects were dependent on the presence of light, and were not present in the absence of light [35]. Additionally, Galic and Persinger [36] examined whether geomagnetic disturbances are associated with pain thresholds by exposing adult mice to a hotplate paradigm once weekly for 52 weeks during the dark cycle. They found that hotplate latency was significantly and inversely correlated with daily geomagnetic intensity 3 days prior to testing. Higher levels of geomagnetic activity 3 days prior to a given hotplate trial tended to be associated with shorter response latencies in subjects, suggesting lower pain thresholds or less analgesia [36]. In addition, there have been some reports that electromagnetic fields affect human pain thresholds [32]. The administration of opioid analgesics in patients with known bipolar disorder provides an opportunity to observe some opioid-related mood-elevating changes [37]. Therefore, there is a possibility that geomagnetic disturbances have an effect on opioid receptors and change people's mood state.

One important limitation of our study was its ecological study design. Therefore, we cannot determine the causal relationship between geomagnetic disturbances and suicides. In addition, it is well known that geomagnetic disturbances vary with the season due to geophysical effects [38]. Likewise, suicide rates vary with the season presumably due to sociological reasons [39]. Thus, there will be a statistical association between geomagnetic disturbances and suicide even if there is no causal connection between them.

In this study, we generated a hypothesis that geomagnetic disturbances may trigger male suicides. In Japan, geomagnetic fields have been observed at some observatory stations, but there are no stations in prefectures with relatively high rates of suicide (e.g., Akita prefecture). For future research, we would like to measure the environmental magnetic fields in certain prefectures with relatively high rates of suicide and those with lower rates of suicide to verify the relationship between geomagnetic disturbance and the number of suicides.

Acknowledgments We would like to thank Prof. Toshihiko Iyemori (Data Analysis Center for Geomagnetism and Space Magnetism, Graduate School of Science, Kyoto University, Kyoto, Japan) for his insightful comments and suggestions.

Conflict of interest Harue Tada received a research grant from the Ministry of Education, Culture, Sports, Science and Technology, with a Grant-in-Aid for Young Scientists (B), 21790581, 2009.

\section{References}

1. Värnik P. Suicide in the world. Int J Environ Res Public Health. 2012;9:760-71.

2. Gaynes BN, West SL, Ford CA, Frame P, Klein J, Lohr KN. Screening for suicide risk in adults: a summary of the evidence for the US Preventive Services Task Force. Ann Intern Med. 2004;140:822-35.

3. Reichmanis M, Perry FS, Marino AA, Becker RO. Relation between suicide and the electromagnetic field of overhead power lines. Physiol Chem Phys. 1979;11:395-403.

4. van Wijngaarden E, Savitz DA, Kleckner RC, Cai J, Loomis D. Exposure to electromagnetic fields and suicide among electric utility workers: a nested case-control study. West J Med. 2000;173:94-100.

5. Chew KSY, McCleary R. The spring peak in suicides: a crossnational analysis. Soc Sci Med. 1995;40:223-30.

6. Heerlein A, Valeria C, Medina B. Seasonal variation in suicidal deaths in Chile: its relationship to latitude. Psychopathology. 2006;39:75-9.

7. Partonen T, Haukka J, Nevanlinna H, Lönnqvist J. Analysis of the seasonal pattern in suicide. J Affect Disord. 2004;81:133-9.

8. Perry S, Pearl L. Power frequency magnetic field and illness in multi-storey blocks. Public Health. 1988;102:11-8.

9. Gordon C, Berk M. The effect of geomagnetic storms on suicide. S Afr Psychiatry Rev. 2003;6:24-7.

10. Berk M, Dodd S, Henry M. Do ambient electromagnetic fields affect behaviour? A demonstration of the relationship between geomagnetic storm activity and suicide. Bioelectromagnetics. 2006;27:151-5.

11. Brahic C. Does the Earth's magnetic field cause suicides? NewScientist; 2008. http://www.newscientist.com/article/dn13769.

12. Ganjavi O, Schell B, Cachon JC, Porporino F. Geophysical variables and behavior: XXIX. impact of atmospheric conditions on occurrences of individual violence among Canadian penitentiary populations. Percept Mot Skills. 1985;61:259-75. 
13. Stoupel E, Kalediene R, Petrauskiene J, Starkuviene S, Abramson E, Israelevich P, Sulkes J. Suicide-homicide temporal interrelationship, links with other fatalities, and environmental physical activity. Crisis. 2005;26:85-9.

14. Mandea M, Korte M. Geomagnetic Observations and Models. 1st ed. Berlin: Springer; 2010.

15. Ptitsyna NG, Villoresi G, Dorman LI, Iucci N, Tyasto MI. Natural and man-made low-frequency magnetic fields as a potential health hazard. Phys Uspekhi. 1998;41:687-709.

16. Ministry of Health, Labour and Welfare, Japan. Demographic survey, stored statistics tables, by-prefecture version: deaths and causes of death; table 3-00 (national). http://www.e-stat.go.jp.

17. Henshaw DL, Reiter RJ. Do magnetic fields cause increased risk of childhood leukemia via melatonin disruption? Bioelectromagnetics. 2005;26(Suppl 7):S86-97.

18. World Health Organization (WHO). Suicide rates per 100,000 by country, year and sex, 2011. http://www.who.int/mental_health/ prevention/suicide_rates/en/.

19. Japan Meteorological Agency. Geomagnetic observatory; observation materials, $\mathrm{k}$ index list, display of $\mathrm{k}$ index list, three-hourrange indices, k (utc). http://www.kakioka-jma.go.jp.

20. Statistics Bureau, Ministry of Internal Affairs and Communications. Labor survey, basic aggregation, all prefectures (attached list); overall unemployment rate (seasonally adjusted values) from 1953. http://www.e-stat.go.jp.

21. Jevons WS. Commercial crises and sun-spots. Nature. 1878;19:33-7.

22. Otsu A, Chinami M, Morgenthaler S, Kaneko Y, Fujita D, Shirakawa $\mathrm{T}$. Correlations for number of sunspots, unemployment rate, and suicide mortality in Japan. Percept Mot Skills. 2006;102: 603-8.

23. Solar Influences Data Analysis Center (SIDC). Monthly and monthly smoothed sunspot number. http://sidc.oma.be/sunspotdata/.

24. Japan Meteorological Agency. Past weather data search. http:// www.jma.go.jp/jma/index.html.

25. Statistics Bureau, Ministry of Internal Affairs and Communications. National census, population estimates, 1999-2010.

26. Kavaliers M, Ossenkopp KP, Prato FS, Innes DGL, Galea LAM, Kinsella DM, Perrot-Sinal TS. Spatial learning in deer mice: sex differences and the effects of endogenous opioids and $60 \mathrm{~Hz}$ magnetic fields. J Comp Physiol A. 1996;179:715-24.

27. Mulligan S, Persinger MA. Perinatal exposures to rotating magnetic fields 'demasculinize' neuronal density in the medial preoptic nucleus of male rats. Neurosci Lett. 1998;253:29-32.
28. Choleris E, Thomas AW, Ossenkopp K-P, Kavaliers M, Valsecchi P, Prato FS. Sex differences in conditioned taste aversion and in the effects of exposure to a specific pulsed magnetic field in deer mice Peromyscus maniculatus. Physiol Behav. 2000;71: 237-49.

29. Jiang M-L, Han T-Z, Pang W, Li L. Gender- and age-specific impairment of rat performance in the Morris water maze following prenatal exposure to an MRI magnetic field. Brain Res. 2004;995:140-4.

30. Mitsutake G, Otsuka K, Hayakawa M, Sekiguchi M, Cornélissen G, Halberg F. Does Schumann resonance affect our blood pressure? Biomed Pharmacother. 2005;59(Suppl 1):S10-4.

31. Cason AM, DenBleyker M, Ferrence K, Smith JC, Houpt TA. Sex and estrous cycle differences in the behavioral effects of high-strength static magnetic fields: role of ovarian steroids. Am J Physiol Regul Integr Comp Physiol. 2006;290:R659-67.

32. Del Seppia C, Ghione S, Luschi P, Ossenkopp K-P, Choleris E, Kavaliers M. Pain perception and electromagnetic fields. Neurosci Biobehav Rev. 2007;31:619-42.

33. Thomas AW, Kavaliers M, Prato FS, Ossenkopp K-P. Pulsed magnetic field induced "analgesia" in the land snail, Cepaea nemoralis, and the effects of mu, delta, and kappa opioid receptor agonists/antagonists. Peptides. 1997;18:703-9.

34. Thomas AW, Kavaliers M, Prato FS, Ossenkopp K-P. Antinociceptive effects of a pulsed magnetic field in the land snail, Cepaea nemoralis. Neurosci Lett. 1997;222:107-10.

35. Prato FS, Kavaliers M, Thomas AW. Extremely low frequency magnetic fields can either increase or decrease analgaesia in the land snail depending on field and light conditions. Bioelectromagnetics. 2000;21:287-301.

36. Galic MA, Persinger MA. Lagged association between geomagnetic activity and diminished nocturnal pain thresholds in mice. Bioelectromagnetics. 2007;28:577-9.

37. Schaffer CB, Nordahl TE, Schaffer LC, Howe J. Mood-elevating effects of opioid analgesics in patients with bipolar disorder. J Neuropsychiatry Clin Neurosci. 2007;19:449-52.

38. Lyatsky W, Hamza AM. Seasonal and diurnal variations of geomagnetic activity and their role in space weather forecast. Can J Phys. 2001;79:907-20.

39. Lee H-C, Lin H-C, Tsai S-Y, Li C-Y, Chen C-C, Huang C-C. Suicide rates and the association with climate: a population-based study. J Affect Disord. 2006;92:221-6.

40. Kay RW. Geomagnetic storms: association with incidence of depression as measured by hospital admission. Br J Psychiatry. 1994;164:403-9. 